\title{
In-vitro toxicity study of poly(alkylphenol) as vulcanizing agent
}

\author{
Joon Woo Chon ${ }^{1}$, Ji Yun Lee ${ }^{1}$, Yoon Ju Song ${ }^{2}$, Jin Hwan Kim and Dong June Chung ${ }^{1 *}$ (1)
}

\begin{abstract}
In this study, cytotoxicity of various novel poly(alkylpehnol) derivatives which, one of constituent for vulcanizing agent, could be adjusted in medical elastic rubber applications were investigated under various conditions of cytotoxicity test.

By MTT-assay which according to ISO 10993-5 regulation, we could figure out cell viability of mouse fibroblast in various sample conditions. Furthermore, by Live \& Dead Cell assay, we could get colorimetric cell viability via fluorescence images.
\end{abstract}

Keyword: Elastic rubber, Medical application, Alkyl phenol vulcanizing agent, Cytotoxicity

\section{Background}

Elastic rubbers are used numerous applications in modern life and in many types of clinical equipments $[1,2]$. The use of elastic rubber for medical devices was begun when the rubber industry started especially after the discovery of vulcanized natural rubber. The elasticity and flexibility make it good approach to medical application [3]. Elastic rubber was first used in medical devices in the sealing cab of disposable medical syringe and therapeutic injection ampoules. The vulcanizing agent is one of the most important constituent of rubber and establishes its properties during mixing and molding. After vulcanization, its mechanical properties (elasticity and flexibility) are enhanced. In addition to these properties, biocompatibility and non-toxicity are especially important for clinical applications of medical rubber. However vulcanizing agents that contain nitrogen frequently produced nitrosamine as a decomposition product when the rubber waste was incinerated; this is undesirable because nitrosamine is toxic to humans [4]. Furthermore, nitrosamine is carciogenic $[5,6]$. Thus, the development of nitrogen-free vulcanizing agent is one of the most important challenges for preventing potential toxicological issues.

\footnotetext{
* Correspondence: djchung@skku.edu

'Department of Polymer Science and Engineering, Sungkyunkwan University, Suwon 16419, Korea

Full list of author information is available at the end of the article
}

To overcome this problem, poly(alkylphenol) disulfide reagents are believed to be promising nontoxic vulcanizing agent. Poly(alkylphenol) sulfide which derived from various configuration of alkyl group with sulfur content has potential double sulfur bridges so that many great deal on vulcanizing agent [7].

Furthermore, one of important benefit by using poly(alkylphenol) sulfide as vulcanizing agent to adjust medical device is that these chemical compounds are not only nitrosamine free but also better heat resistance, dynamic fatigue properties, and enhanced adhesion [8].

\section{Main text \\ Materials and methods}

We investigated the cytotoxicity of various poly(alkylphenol) disulfide vulcanizing agents, with the aim of using these agents for clinical application. Novel poly(alkylphenol) derivatives were synthesized and kindly supplied by M\&B GreenUs Co. (Seoul, Korea) (Fig. 1 and Table 1). For the synthesis of polyphenol, P1, P2 and P3, the appropriate monomers (phenol, $p$-tert-octylphenol, $p$ (1,1-dimethylethyl) phenol, and $p$-tert-butylphenol, respectively) were reacted with $\mathrm{S}_{2} \mathrm{Cl}_{2}$ in toluene at $150 \sim 180{ }^{\circ} \mathrm{C} / 4 \sim 6 \mathrm{~h}$ to obtain macromolecules by forming sulfuric bridge between the monomers. To control the temperature of the exothermic reaction, $\mathrm{S}_{2} \mathrm{Cl}_{2}$ solution was slowly added by dropwise using a funnel. Gaseous $\mathrm{HCl}$, generated during the formation of $\mathrm{S}-\mathrm{S}$ bonds, was removed using an $\mathrm{HCl}$ trap under 
<smiles>CSc1cccc(SC)c1O</smiles>

a<smiles>CC(C)(C)c1cc(S(C)(C)C)c(O)c(S(C)(C)S(C)(C)c2cc(C(C)(C)C)cc(S(C)(C)C)c2O)c1</smiles>

e<smiles>CC(C)(C)Sc1cc(C(C)(C)C)cc(S(C)(C)c2cc(C(C)(C)C)cc(S(C)(C)C)c2O)c1O</smiles><smiles></smiles>

C<smiles>C[13CH](C)c1cc([13CH](C)C)c(O)c(C(C)(C)C)c1</smiles>

d<smiles>CC(C)(C)c1cc(S(C)(C)C)c(O)c(S(C)(C)c2cc(C(C)(C)C)cc(S(C)(C)C)c2O)c1</smiles>

b<smiles>CC(C)(C)Cc1cc(C(C)(C)CC(C)(C)C)cc([As])c1O</smiles>

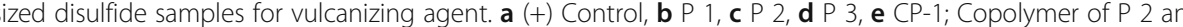
P 3 (1:3, monomer mol ratio in feed), $\mathbf{f}$ CP- 2; Copolymer of P 2 and $P 3$ (3:1, monomer mol ratio in feed), $\mathbf{g}$ CP-3; Copolymer of P 2 and $P 3$ (1:1, monomer mol ratio in feed)

a nitrogen stream. The resultant polymers were separated by distillation at $200{ }^{\circ} \mathrm{C}$ for $0.5 \sim 1 \mathrm{~h}$. For the synthesis of novel copolymer type vulcanizing agent $(\mathrm{CP}-1, \mathrm{CP}-2$, and CP-3), two monomers ( $p$ - $(1,1-$ dimethylethyl) phenol and $p$-tert-butylphenol) were copolymerized with $\mathrm{S}_{2} \mathrm{Cl}_{2}$, under the same reaction conditions mentioned above, in various molar feeding ratios (Table 1). The molecular weight $(\mathrm{Mw})$ of synthesized homopolymer and copolymer was measured GPC(eluent; THF, eluting rate; $0.8 \mathrm{ml} / \mathrm{min}$, column; Styragel Guard column, Styragel HR(High Resolution), Styragel $4 \mathrm{E}$ and Styragel $5 \mathrm{E}$ by Waters Co, Ltd., Milford, MA, USA). The dermal $\mathrm{LD}_{50}$ values in rabbits of these two monomers are lower than those of pure phenol and therefore $p$-tert-octylphenol $[9,10], p$-(1,1-dimethylethyl)phenol and $p$-tert-butylphenol were selected as nontoxic

Table 1 Various formulation ratios of samples

\begin{tabular}{|c|c|c|c|c|c|}
\hline Sample & Constituent & $\begin{array}{l}\text { Solvent for } \\
\text { samples }\end{array}$ & $\begin{array}{l}\text { Sample concentrations } \\
\text { in DMSO (mol \%) }\end{array}$ & $\begin{array}{l}\text { Dilution ratio with } \\
\text { PBS (wt \%) }\end{array}$ & $\begin{array}{l}\text { Mw measured } \\
\text { by GPC }\end{array}$ \\
\hline PBS & Phosphate Buffered Solution & DMSO & - & - & - \\
\hline$(-)$ control & Pure phenol (Sigma-Aldrich Co., Ltd., St. Louis, USA) & DMSO & $1 \%, 5 \%, 10 \%$ & $1 \%, 5 \%, 10 \%$ & - \\
\hline$(+)$ control & Poly phenol disulfide (GreenUS M\&B Co., Seoul, Korea) & DMSO & $1 \%, 5 \% 10 \%$ & $1 \%, 5 \%, 10 \%$ & 802 \\
\hline P1 & Poly p-octylphenol disulfide (GreenUS M\&B Co., Seoul, Korea) & DMSO & $1 \%, 5 \%, 10 \%$ & $1 \%, 5 \%, 10 \%$ & 2,027 \\
\hline P2 & $\begin{array}{l}\text { Poly p-(1,1 dimethyl ethyl) phenol disulfide (GreenUS M\&B Co., } \\
\text { Seoul, Korea) }\end{array}$ & DMSO & $1 \%, 5 \%, 10 \%$ & $1 \%, 5 \%, 10 \%$ & 2,116 \\
\hline P3 & $\begin{array}{l}\text { Pol p-tert-butylphenol disul fi de (GreenUS M\&B Co., Seoul, } \\
\text { Korea) }\end{array}$ & DMSO & $1 \%, 5 \%, 10 \%$ & $1 \%, 5 \%, 10 \%$ & 2,365 \\
\hline CP-1 & $\begin{array}{l}\text { Copolymer of P2 and P3 (1:3, in monomer feeding ratio) } \\
\text { (GreenUS M\&B Co., Seoul, Korea) }\end{array}$ & DMSO & $1 \%, 5 \%, 10 \%$ & $1 \%, 5 \%, 10 \%$ & 2,772 \\
\hline CP-2 & $\begin{array}{l}\text { Copolymer of P2 and P3 (3:1, in monomer feeding ratio) } \\
\text { (GreenUS M\&B Co., Seoul, Korea) }\end{array}$ & DMSO & $1 \%, 5 \%, 10 \%$ & $1 \%, 5 \%, 10 \%$ & 2,728 \\
\hline CP-3 & $\begin{array}{l}\text { Copolymer of P2 and P3 (1:1, in monomer feeding ratio) } \\
\text { (GreenUS M\&B Co., Seoul, Korea) }\end{array}$ & DMSO & $1 \%, 5 \%, 10 \%$ & $1 \%, 5 \%, 10 \%$ & 2,632 \\
\hline
\end{tabular}


vulcanizing agent for copolymer synthesis and their cytotoxicity was compared to that of control samples. Pure phenol, PBS (phosphate buffered solution), and synthesized polyphenol were used as control.

To compare the cytotoxic effects of the vulcanizing agents like as synthesized polymeric vulcanizing agents, phenol((-) control), and polyphenol disulfide $((+)$ control), 9 samples were dissolved in DMSO at $1 \mathrm{~mol} \%, 5 \mathrm{~mol} \mathrm{\%}$, and $10 \mathrm{~mol} \%$ for $1 \mathrm{~h}$ at room temperature. These sample solutions (PBS, (+) control, (-) control and the 6 samples) were then diluted in PBS to $1 \mathrm{wt} \%, 5 \mathrm{wt} \%$, and $10 \mathrm{wt} \%$ for cytotoxicity assays using fibroblasts. The MTT assay and the Live \& Dead Cell assay were conducted to evaluate the cytotoxicity of each compound. These assays work by analyzing cell viability $[11,12]$. Commercial kits were used for the two assays (Sigma-Aldrich Co., Ltd., St. Louis, MO, USA). All experiments were carried out 5 times. Briefly, L-929 mouse fibroblasts (obtained from the Korean Cell Line Bank Co., Korea) were seeded $\left(1 \times 10^{5}\right.$ cell/ $\mathrm{mL}$ ) into each well of a tissue culture polystyrene dish (TCPS). The cell were incubated at $36.5{ }^{\circ} \mathrm{C}$ in a $5 \% \mathrm{CO}_{2}$ with $10 \%$ FBS (fatal bovine serum) and $1 \%$ penicillinstreptomycin. For the assay, the 9 solutions described above were added to the TCPS wells and incubated with cells for 2 days. The MTT assay was performed according to the ISO 10993-5 guidence [13]. Briefly, DMEM and MTT were added to each well and the mixture was incubated for $4 \mathrm{~h}$ under the same conditions. After this incubation, the supernatant was removed from each well by aspiration. Next, DMSO and glycine buffer were sequentially added to each well. Finally, the UV-Vis absorbance of each well was measured at $570 \mathrm{~nm}$ using a SpectraMax M5 plate reader (Molecular Devices, Co., Seoul, Korea).
For the Live \& Dead Cell assay, samples were prepared as for the MTT assay. Next, calcein-AM and propidium iodide (PI) were added to each well and incubate for $15 \mathrm{~min}$ at $36.5{ }^{\circ} \mathrm{C}$ in $5 \% \mathrm{CO}_{2}$ atmosphere. Fluorescence images were captured and analyzed using a Nikon Eclipse Ti microscope (Nikon Instruments Inc., Tokyo, Japan). Furthermore, ALP assay was carried out with Alkaline Phosphatase Assay Kit (AnaSpec Co., Inc., Fremont, CA, USA) to determine changes in activity of phosphatase which derived from cell membrane $[14,15]$. The biological sample treating was more harsh than MTT assay and Live \& Dead Cell assay. Concentration range of every samples for ALP assay were $10 \mathrm{~mol} \%$ to $40 \mathrm{~mol} \%$. Each activity of phosphatase were measured at $405 \mathrm{~nm}$ using a SpectraMax M5 plate reader (Molecular Devices, Co., Seoul, Korea).

\section{Results and discussion}

The MTT assay is one of the most powerful method for analyzing cell viability and is based on a colorimetric assay that measures the metabolic activity in living cells. In this asssy, MTT tetrazolium (yellow) is reduced to MTT formazan, which becomes purple after mitochondrial reduction in living cells. The UV-Vis absorbance change at $570 \mathrm{~nm}$ is directly proportional to the amount of MTT formazan reduction. As shown in Fig. 2, treatment with the $1 \mathrm{~mol} \%$ concentration of the disulfide sample solutions (6 kinds) and of the $(+)$ control sample (each of which was diluted by PBS to 1,5 , and $10 \mathrm{wt} \%$ ) resulted in over $80 \%$ viability. Strikingly, this viability was maintained even up to the $10 \mathrm{wt} \%$ dilution. These results indicate that all samples (with the exception of the (-) control at $10 \mathrm{wt} \%)$ can be classified as nontoxic according to the ISO guidelines. In contrast, the viability

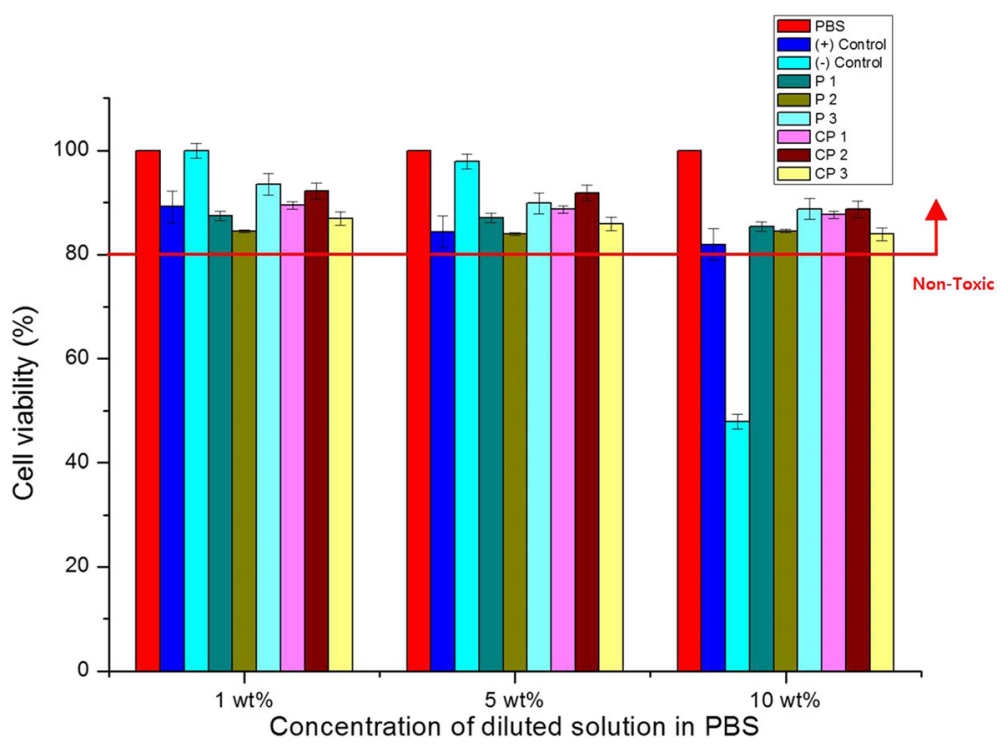

Fig. 2 Cell viability of $1 \mathrm{~mol} \%$ of disulfide sample solutions 


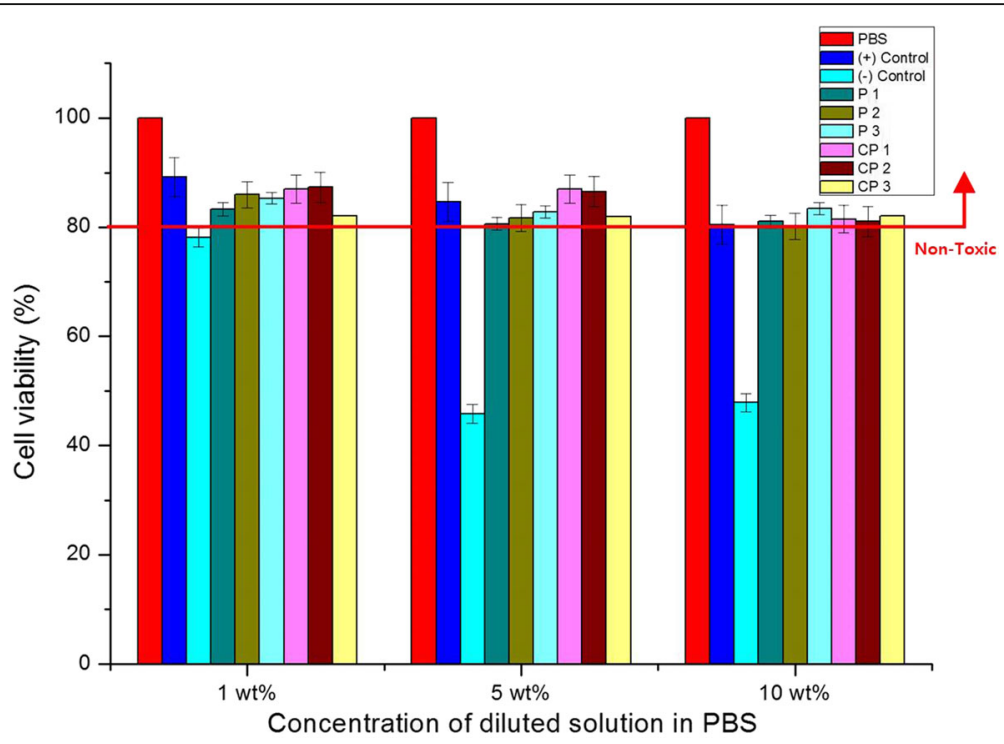

Fig. 3 Cell viability of $10 \mathrm{~mol} \%$ of disulfide sample solutions

of cells treated with pure phenol, which was used as negative control, decreased rapidly to less than $50 \%$ for the $10 \mathrm{wt} \%$ dilution. These results demonstrate the noncytotoxicity of the 6 synthesized compounds and the $(+)$ control(polyphenol), in contrast to the (-) control (pure phenol). In particular, cells treated with the copolymer samples showed enhanced viability compared to cells treated with the $(+)$ control, even up though the $10 \mathrm{wt} \%$ dilution.

We next tested the cytotoxicity of $10 \mathrm{~mol} \%$ concentrations of the disulfide sample solutions, a relatively high concentration considering the typical concentrations of vulcanizing agents in rubber processing. As shown in Fig. 3, the overall viabilities of cells treated with the various solutions (each of which was diluted to $1 \mathrm{wt} \%, 5 \mathrm{wt} \%$, and $10 \mathrm{wt} \%$ in PBS) at $10 \mathrm{~mol} \%$ were decreased compared with the corresponding viabilities of the cells treated with the $1 \mathrm{~mol} \%$ solutions. However, cell viability always remained above $80 \%$ comparing to that of control at the $10 \mathrm{wt} \%$ dilutions, with the exception of cells treated with the polymeric vulcanizing agents, which were close to $80 \%$ viable after treatment

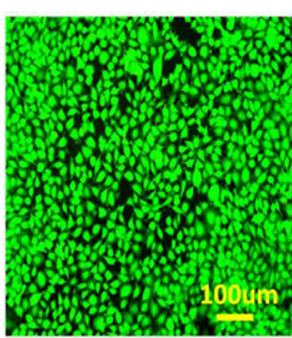

PBS

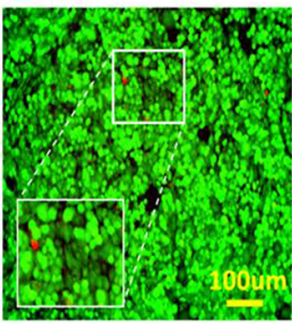

P 3

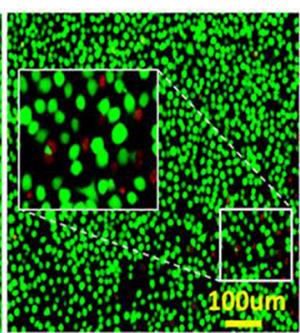

(+) Control

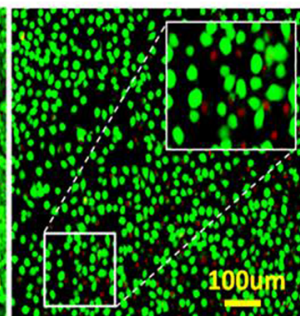

CP 1

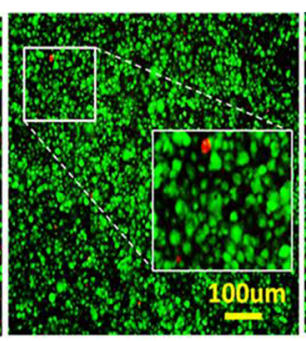

P 1

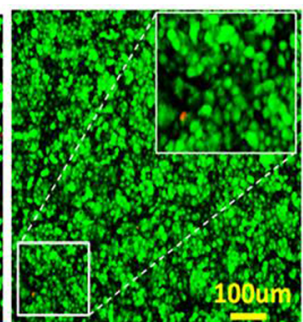

CP 2

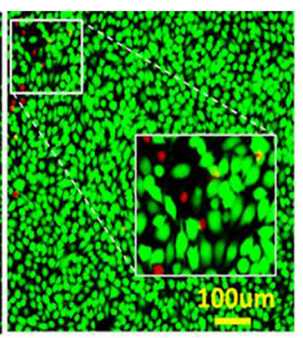

P 2

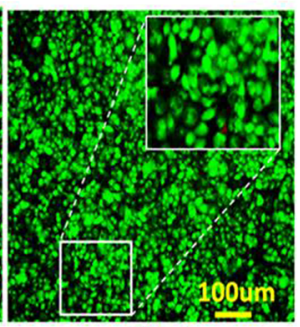

CP 3

Fig. 4 Image of Cell viability of $1 \mathrm{~mol} \%$ of disulfide solution via Live \& Dead Cell-assay (Diluted by PBS in 10 wt \%). Dead cell (Red Spot) was emphasized with square mark 


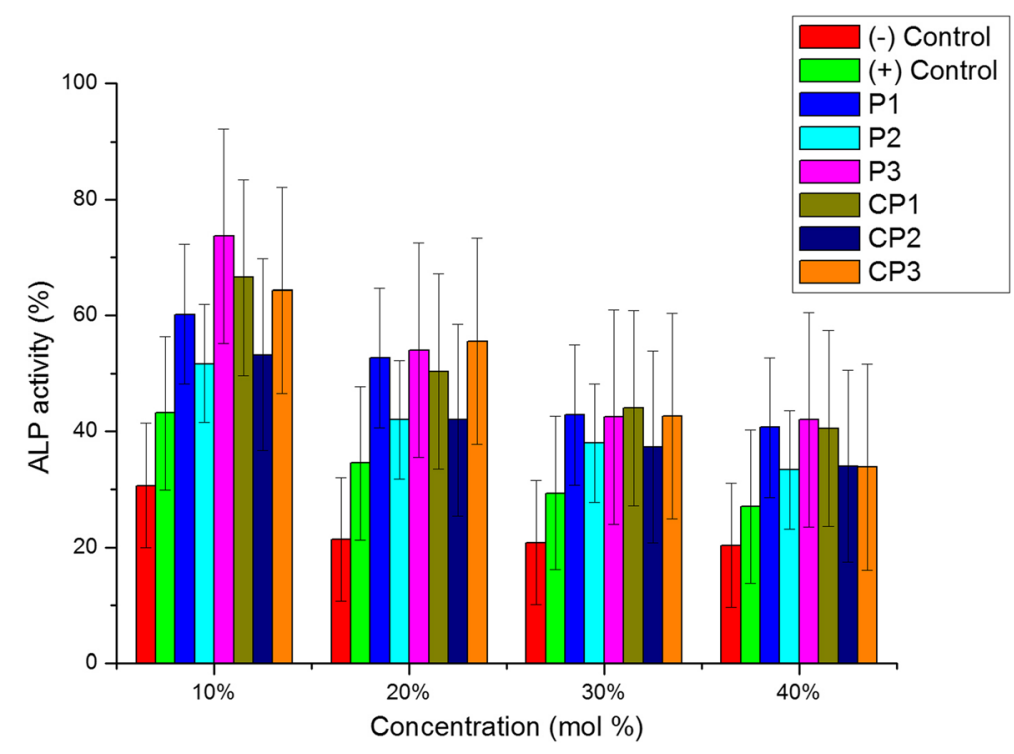

Fig. 5 ALP activity of various mol \% of each samples

with the 5 and 10 wt\% dilutions. This means that the poly(alkylphenol) samples were toxic at high concentrations $(10 \mathrm{~mol} \%)$. However, the viability of cells treated with pure phenol showed a drastic decrease. Furthermore, compared with cells treated with $10 \mathrm{~mol} \%$ of a disulfide sample solution, cells treated with pure phenol (even diluted phenol) showed much lower viability.

We also performed a colorimetric cell viability assay as a complementary technique. To this end, we used the Live \& Dead Cell assay. Briefly, $1 \mathrm{~mol} \%$ disulfide solutions were prepared by diluting the $10 \mathrm{wt} \%$ solutions with PBS. The treated samples were observed by fluorescence microscopy. The two probes used in this assay have different fluorescence colors based on whether they recognize live or dead cells. Live cells are distinguished by green fluorescence, which results from esterase-mediated hydrolysis of the acetoxymethyl ester bond in calcein AM. On the other hand, the ethidium homodimer binds to DNA in dead cells and produces red fluorescence.

As shown in Fig. 4, red cells were observed in many of the TCPS wells, but most of the cells in the TCPS were green after each of the predetermined culture times. This finding indicates that most of the cells remained alive after treatment with the $1 \mathrm{~mol} \%$ solutions (which had been generated from the $10 \mathrm{wt} \%$ solutions by dilution with PBS). Comparison of the proportions of dead cells (red fluorescence) to live cells (green fluorescence) in the images of the homopolymer (P1 P3) and copolymer (CP-1 CP-3)-treated wells revealed that the copolymers were much less cytotoxic than the homopolymers. These results are consistant with the MTT assay results (Fig. 2), which indicate that the copolymer are all nontoxic.
From Fig. 5, ALP activity of every samples were marked higher level than the (-) control (Pure phenol) at $10 \mathrm{~mol} \%$ of concentration in DMSO. Even concentration increment till $40 \mathrm{~mol} \%$, ALP activity of homopolymers and copolymers still marked higher level than the (-) control. These results indicated that cytotoxicity of each samples showed generally similar tendency with MTT-assay and Live \& Dead Cell assay.

\section{Conclusion}

In this study, we used the MTT assay and the Live \& Dead Cell assay to test the cytotoxicity of various polymeric disulfide samples that could potentially be used as vulcanizing agent in medical elastic rubber. Every synthesized sample was classified as nontoxic according to the ISO standards. Fluorescence microscopy revealed many live cells on the TCPS, even after treatment with the disulfide sample solutions. Furthermore, each sample was less cytotoxic than pure phenol, and yielded similar viability compared with the $(+)$ control under the same diluting conditions. From ALP assay, every sample showed higher activity level than both control even concentration increased. Further work will include to invivo experiments of toxicity of our synthesized disulfide samples. To this end, skin sensitization test and inflammation analysis will be carried out in animal modles to determine the biological response to our disulfide samples.

\section{Abbreviations}

CP-1: Copolymer of P2 and P3 (1:3, in monomer feeding ratio); CP-2: Copolymer of P2 and P3 (3:1, in monomer feeding ratio); CP-3: Copolymer of P2 and P3 (1:1, in monomer feeding ratio); P1: Poly p-octylphenol disulfide; P2: Poly $p$-(1,1dimethylethyl)phenol disulfide; P3: Poly $p$-tert-butylphenol disulfide 


\section{Acknowledgments}

Not applicable.

\section{Funding}

This work was supported by the Technology Innovation Program (Project No.; 10052324, Project Title; Developments of manufacturing technologies and preparations for various disulfide based fine chemicals), which is funded by the Ministry of Trade, Industry \& Energy (MOTIE, Korea).

\section{Availability of supporting data}

All data generated or analyzed during this study are included in this published article.

\section{Authors' contributions}

JWC researched and wrote experiment of all the manuscript. JYL and YJS carried out preparation and synthesis of samples. JWK and DJC organized all parts of this research. All author read and approved the final manuscript.

\section{Competing interests}

The authors declare that they have no competing interests.

\section{Consent for publication}

Authors consent for publication.

\section{Ethics approval and consent to participate}

Not applicable.

\section{Author details}

'Department of Polymer Science and Engineering, Sungkyunkwan University, Suwon 16419, Korea. ${ }^{2}$ M\&B GreenUs Co, Ltd, \#1016, 278, Beotkkot-ro,

Geumcheon-gu, Seoul 08511, Korea.

\section{Received: 20 July 2016 Accepted: 28 October 2016}

Published online: 14 November 2016

\section{References}

1. Airaudo CB, Gayte-Sorbier A, Creusevau R, Dumont R. Pharm Res. 1987:4:237.

2. Airaudo CB, Gayte-Sorbier A, Momburg R, Laurentz P. J Biomater Sci Polym. 1989;1:231.

3. Mooribroek H, Cornish K. Appl Microbiol Biotechnol. 2000;53:355.

4. Fajen JM, Carson GA, Rounbehler DP, Fan TY, Vita R, Goff UE, Wolf MH, Edwards GS, Fine DH, Reinhold V, Biemann K. Science. 1979;205:1262.

5. Lijinsky W. Mol Toxicol. 1987;1:107.

6. Fiddler W, Pensabene JW, Kimoto WI. Am Ind Hyg Assoc J. 1985;46:463.

7. Wolf GM, Deger TE, Cramer HI, DeHilster CC. Ind Eng Chem Res. 1946;38:1157.

8. Zhang H, Datta RN, Talma AG, Noordermeer JWM. Macromol Mater Eng. 2010;18:67.

9. Smyth HF, Carpenter CP, Weil CS, Pozzani UC, Striegel JA, Nycum JS. Am Ind Hyg Assoc J. 1969:30:470

10. Kim J-H, Yoon M-H. J Environ Sci Int. 2014;23(2):313.

11. Wu H, Zhu L, Torchilin VP. Biomaterials. 2013;34:1213.

12. Decherchi P, Cochard P, Gauthier P. J Neurosci Methods. 1997;71:205.

13. ISO 10993-5. International standard. 3rd ed. 2009.

14. Kwon JH, Park HC, Zhu T, Yang HC. Biomater Res. 2015;19:8,

15. Ariffin SHZ, Kermani S, Wahab PMA, Senafi S, Ariffin ZZ, Razak MA. Sci World J. 2012;2012:7.

Submit your next manuscript to BioMed Central and we will help you at every step:

- We accept pre-submission inquiries

- Our selector tool helps you to find the most relevant journal

- We provide round the clock customer support

- Convenient online submission

- Thorough peer review

- Inclusion in PubMed and all major indexing services

- Maximum visibility for your research

Submit your manuscript at www.biomedcentral.com/submit
Biomed Central 